\title{
Hepatoprotective effect of water extract from Chrysanthemum indicum L. flower
}

\author{
Sang Chul Jeong, Sang Min Kim, Yong Tae Jeong and Chi Hyun Song*
}

\begin{abstract}
Background: Chrysanthemum indicum L. flower (CIF) has been widely used as tea in Korea. This study aims to investigate the hepatoprotective effect of the hot water extract of CIF (HCIF) in in vitro and in vivo systems.

Methods: Hepatoprotective activities were evaluated at 250 to $1000 \mu \mathrm{g} / \mathrm{mL}$ concentrations by an in vitro assay using normal human hepatocytes (Chang cell) and hepatocellular carcinoma cells (HepG2) against CCl $_{4}$-induced cytotoxicity. Cytochrome P450 2E1, which is a key indicator of hepatic injury, was detected by western blot analysis using rabbit polyclonal anti-human CYP2E1 antibody. An in vivo hepatoprotective activity assay was performed at 1000 to $4000 \mathrm{\mu g} / \mathrm{mL}$ concentrations on $\mathrm{CCl}_{4}$-induced acute toxicity in rats, and the serum levels of glutamic oxaloacetic transaminase (GOT), glutamic pyruvic transaminase (GPT), alkaline phosphatase (ALP) and lactate dehydrogenase (LDH) were determined by standard enzyme assays.

Results: The hepatoprotective effects of HCIF significantly reduced the levels of GOT $(60.1 \%, P=0.000)$ and GPT $(64.5 \%, P=0.000)$ compared with the vehicle control group $\left(\mathrm{CCl}_{4}\right.$ alone). The survival rates of HepG2 and Chang cells were significantly improved compared with the control group $[82.1 \%(P=0.034)$ and $62.3 \%(P=0.002)$, respectively]. HCIF $[50 \mathrm{mg} / \mathrm{kg}$ body weight (BW)] treatment significantly reduced the serum levels of GOT (49.5\%, $P=0.00)$, GPT (55.5\%, $P=0.00), \operatorname{ALP}(30.8 \%, P=0.000)$ and LDH $(45.6 \%, P=0.000)$ compared with the control group in this in vivo study. The expression level of cytochrome P450 2E1 (CYP2E1) protein was also significantly decreased at the same concentration (50 $\mathrm{mg} / \mathrm{kg} \mathrm{BW;} P=0.018$ ).
\end{abstract}

Conclusion: $\mathrm{HClF}$ inhibited bioactivation of $\mathrm{CCl}_{4}$-induced hepatotoxicity and downregulates CYP2E1 expression in vitro and in vivo.

\section{Background}

The liver is the major organ for the metabolism of xenobiotics and drugs. $\mathrm{CCl}_{4}$ is a widely used chemical and causes severe liver tissue damage by undergoing biotransformation by the cytochrome $\mathrm{P} 450$ system into a trichloromethyl free radical $\left(\mathrm{CCl}_{3}{ }^{\circ}\right)$ and transformation into a highly reactive trichloromethylperoxy free radical $\left(\mathrm{CCl}_{3} \mathrm{O}_{2}{ }^{\circ}\right)$. The resulting free radical damages liver cell membranes and organelles and causes swelling, necrosis of hepatocytes and the release of cytosolic enzymes, such as glutamic oxaloacetic transaminase (GOT), glutamic pyruvic transaminase (GPT), alkaline phosphatase (ALP) and lactate dehydrogenase (LDH), into serum and eventually kills cells [1-3]. Oriental traditional medicine has used the aerial parts (stem, leaves and flowers) of

\footnotetext{
*Correspondence: chsong@daegu.ac.kr

Department of Biotechnology, Daegu University, Gyeongsan, Gyeoongbuk 712-714, Republic of Korea
}

Chrysanthemum indicum to treat hypertensive symptoms and several infectious diseases, such as fever and stomatitis [4]. Notably, its flowers, which are used as traditional tea in Korea and China [5], are widely considered to have health benefits. Therefore, we investigated C. indicum L. flowers in this study. Chrysanthemum indicum L. flower (CIF) is a wild herb and has a long history of use as a traditional medicine, mainly for the treatment of inflammation, hypertension and respiratory diseases in Korean and Chinese medicine [6-9]. Several studies have demonstrated that the water extract of C. indicum L. has strong antioxidant effects and inhibitory effects against bacteria and viruses $[10,11]$. In addition, the methanol extract shows inhibitory activity of xanthine oxidase [12]. Several chemical compounds isolated from CIF exhibit inhibitory activity against nitric oxide (NO) in lipopolysaccharide-activated macrophages and rat lens aldose reductase [13]. 
The suppression of cytochrome P450 could result in reduced levels of reactive metabolites from xenobiotic exposure, decreasing liver injury [2,14]. Although several cytochrome $\mathrm{P} 450$ isoforms may metabolize $\mathrm{CCl}_{4}$, the cytochrome P450 2E1 (CYP2E1) isoform, which is ethanol inducible [15-17], has been widely studied. Altering expression of CYP2E1 activity affects susceptibility to hepatic injury from $\mathrm{CCl}_{4}[18,19]$. The expression of individual cytochrome $\mathrm{P} 450$ enzymes is regulated by both endogenous factors and foreign compounds, including drugs and natural compounds [20]. Natural compounds that reduce such bioactivating enzymes could be considered protective candidates against chemically induced toxicity, and CYP2E1 is well recognized for its role in the activation of many chemicals resulting in toxic and carcinogenic effects.

To our knowledge, no study has been conducted to determine the hepatoprotective effect of C. indicum $\mathrm{L}$. against $\mathrm{CCl}_{4}$-induced toxicity. This study aims to investigate the hepatoprotective effect of HCIF in in vitro and in vivo systems.

\section{Methods}

\section{Chemicals and reagents}

Bovine serum albumin (BSA), 3-(4,5-dimethylthiazol-2-yl)2,5-diphenyltetrazolium bromide (MTT), dimethyl sulfoxide (DMSO), sodium bicarbonate, silymarin and $\mathrm{CCl}_{4}$ were purchased from Sigma Chemical Co. (St. Louis, MO, USA). Fetal bovine serum (FBS), RPMI 1640 medium, Dulbecco's modified Eagle's medium (DMEM), trypsinethylenediaminetetraacetic acid (EDTA), penicillin and streptomycin were purchased from GIBCO BRL (Grand Island, NY, USA). GOT, GPT, ALP and LDH assay kits were purchased from Asan Pharmacology Co. (Seoul, Korea). Rabbit polyclonal anti-human CYP2E1 antibody was purchased from Chemicon International Inc. (Temecula, CA, USA). Goat polyclonal anti-human $\beta$-actin antibody, antirabbit IgG and anti-goat IgG were supplied by Santa Cruz Biotechnology (Santa Cruz, CA, USA).

\section{Preparation of hot water extract of CIF (HCIF)}

CIF was obtained from the Daegu traditional medicine market (Seoul, Korea) and authenticated based on its microscopic and macroscopic characteristics by a local botany expert (Dr. Yang, Director, The Research Center for Resource of Oriental Medicine). CIFs (100 g) were ground into powder and decocted with distilled water $(1 \mathrm{~L})$ for $2 \mathrm{~h}$. The decoction was collected twice, filtered (filter paper pore size, $0.45 \mu \mathrm{m}$ ) and lyophilized to obtain the HCIF. The HCIF was dissolved in saline for oral administration to rats.

\section{Cell cultures and viability}

Hepatocellular carcinoma HepG2 (KCLB 88065) and normal human hepatocyte Chang (ATCC CCL-13) cell lines were obtained from the Korean Cell Line Bank (KCLB, Seoul, Korea) and American Type Culture Collection (ATCC, Manassas, VA, USA), respectively. The HepG2 and Chang cells were grown in RPMI-1640 and DMEM supplemented with $10 \% \mathrm{FBS}$, streptomycin $(100 \mathrm{U} / \mathrm{mL})$, penicillin $(100 \mu \mathrm{g} / \mathrm{mL})$ and sodium bicarbonate $(3.7 \mathrm{~g} / \mathrm{mL})$. The cultures were maintained in $100-\mathrm{mm}$ dishes at $37^{\circ} \mathrm{C}$ in a $5 \% \mathrm{CO}_{2}$ humidified incubator (3111, ThermoForma, Ohio, USA). The cell viabilities of HCIF in HepG2 and Chang cells damaged by $\mathrm{CCl}_{4}$ were measured by the MTT assay. Briefly, cells were plated at a density of $2 \times 10^{5}$ cells per well in a 96-well flat-bottom microtiter plate at three concentrations (250, 500 and $1000 \mu \mathrm{g} / \mathrm{mL})$ of HCIF. After a 24-h incubation, the culture media were replaced with media containing $\mathrm{CCl}_{4}(8 \mathrm{mM})$ and incubated for $2 \mathrm{~h}$. At the end of the incubation, $25 \mu \mathrm{L}$ of MTT solution $(5.0 \mathrm{mg} / \mathrm{mL})$ was added to each well and incubated for $4 \mathrm{~h}$ at $37^{\circ} \mathrm{C}$. The cells were then lysed with DMSO $(200 \mu \mathrm{L}$ per well), and the reduced intracellular formazan product was quantified in a Bio-Rad enzyme-linked immunosorbent assay microplate reader (680, Bio-Rad, Hercules, CA, USA) at $540 \mathrm{~nm}$. Cell viability was expressed as the percentage of control absorbance at $540 \mathrm{~nm}$. The data are presented as the mean of triplicate samples \pm SD. Silymarin was used as the positive control [21,22].

\section{Animals}

Male Sprague Dawley rats were purchased from Koatech Laboratory Animal Inc. (Seoul, Korea) and kept for 1 week on a commercial diet under environmentally controlled conditions (room temperature $19-25^{\circ} \mathrm{C}$, relative humidity $50-60 \%)$ with free access to food and water. A controlled $12 \mathrm{~h}$ light/12 h dark cycle was maintained. Rats weighing 180-230 g were used in the $\mathrm{CCl}_{4}$-induced hepatotoxicity study. Animal experiments were performed in accordance with procedures approved by the Ethics Committee for Animal Experimentation of the Korea Food Research Institute.

\section{Treatment of animals}

Liver damage was induced in rats by a $1: 1(\mathrm{v}: \mathrm{v})$ mixture of $\mathrm{CCl}_{4}$ and olive oil by oral gavage as described by previous reports [23-25]. Rats were randomly grouped into four groups of nine animals each. Group I (untreated) rats were treated with olive oil alone $(1 \mathrm{~mL} / \mathrm{kg} \mathrm{BW})$. Group II (control) rats were treated with $\mathrm{CCl}_{4}$ :olive oil $(1 \mathrm{~mL} / \mathrm{kg} \mathrm{BW})$. Group III (positive control) rats were pretreated with silymarin $(50 \mathrm{mg} / \mathrm{kg} \mathrm{BW})$, and groups IV and $\mathrm{V}$ rats were pretreated with HCIF at the level of 50 or $100 \mathrm{mg} / \mathrm{kg}$ BW by oral gavage daily for 7 days before treatment with $\mathrm{CCl}_{4}$ :olive oil (1:1).

\section{Enzymatic analysis}

The cells were washed with phosphate-buffered saline (PBS) and exposed to fresh medium containing $\mathrm{CCl}_{4}$ 
$(100 \mathrm{mM})$ at three concentrations $(1,2$ and $4 \mathrm{mg} / \mathrm{mL})$ of $\mathrm{HCIF}$ or medium alone. After $6 \mathrm{~h}$ of $\mathrm{CCl}_{4}$ treatment, GOT and GPT levels in the medium were measured as described in the assay kits. After removal of the medium, cells were washed twice with ice-cold PBS and used for western blot analysis.

In the animal experiment, all rats were anesthetized with ether $24 \mathrm{~h}$ after dosing with $\mathrm{CCl}_{4}$, and blood was then collected via the carotid artery. Plasma samples were collected from heparinized blood after centrifugation (Combi-514R, Hanil, Seoul, Korea) at 1,518 $\times$ g for $10 \mathrm{~min}$ at $4^{\circ} \mathrm{C}$. The GOT, GPT and LDH levels were measured according to standard methods [26], and serum ALP was estimated by the Kind and Kings method [27].

\section{Western blot analysis of CYP2E1}

After treatment with $\mathrm{CCl}_{4}$, the cells were washed twice with cold PBS and detached with $0.02 \%$ EDTA solution. Subsequently, the cells were treated with IPH lysis buffer and centrifuged at $14,240 \times \mathrm{g}$ for $20 \mathrm{~min}$ at $4^{\circ} \mathrm{C}$. The cells were homogenized in buffer $(\mathrm{pH}$ 8.0) containing $50 \mathrm{mM}$ Tris- $\mathrm{HCl}, 150 \mathrm{mM} \mathrm{NaCl}, 0.02 \% \mathrm{NaN}_{3}, 100 \mu \mathrm{g} / \mathrm{mL}$ phenylmethylsulfonyl fluoride (PMSF), $1 \mathrm{mg} / \mathrm{mL}$ aprotinin and $1 \%$ Triton $\mathrm{X}-100$. Protein concentration was determined by the Bradford protein assay kit (Bio-Rad). Twenty micrograms samples of total cell lysates were size fractionated by SDS-PAGE and electrophoretically transferred to nitrocellulose membranes by a Hoefer electro transfer system (Amersham Pharmacia Biotech Inc., NJ, USA). The membranes were incubated overnight with blocking buffer containing $10 \mathrm{mM}$ Tris- $\mathrm{HCl}, 150 \mathrm{mM} \mathrm{NaCl}, 0.1 \%$ Tween 20 and nonfat dry milk at $4^{\circ} \mathrm{C}$. The membranes were then incubated for $2 \mathrm{~h}$ at room temperature with 1:1000 diluted primary antibodies (rabbit polyclonal antihuman CYP2E1 antibody and goat polyclonal antihuman $\beta$-actin antibody). After washing with blocking buffer 3 times for $10 \mathrm{~min}$, membranes were probed with 1:2000 diluted secondary antibodies (horseradish peroxidase-linked anti-rabbit, anti-goat IgG) for $1 \mathrm{~h}$, washed 3 times for $10 \mathrm{~min}$ and developed with an ECL western blotting detection system (Amersham Pharmacia Biotech Inc.).

\section{Histopathological examination}

Fresh liver tissues, previously trimmed to approximately 2-mm thickness, were placed in plastic cassettes and immersed in neutral buffered formalin for $24 \mathrm{~h}$. Fixed tissues were processed routinely and then embedded in paraffin, sectioned, deparaffinized and rehydrated. The extent of $\mathrm{CCl}_{4}$-induced necrosis was evaluated by morphological changes in liver sections stained with hematoxylin and eosin (Axiolab reflected light microscope, Carl Zeiss, Germany).

\section{Statistical analysis}

The results are presented as the mean \pm SD (calculated from $\mathrm{n}=3$ and $\mathrm{n}=9$ in the in vitro and in vivo studies, respectively). The significance of differences among groups of data was determined using SPSS 18.0 for Windows (IBM, Chicago, IL, USA). Student's t-test was used to compare two independent groups. Statistical significance was accepted for $P$ values of $<0.05$.

\section{Results}

\section{Effect of $\mathrm{HCIF}$ on $\mathrm{CCl}_{4}$-induced hepatotoxicity in vitro}

The $8 \mathrm{mM} \mathrm{CCl} \mathrm{Cl}_{4}$-exposed HepG2 and Chang cells exhibited cell viabilities of $58 \%$ and $39 \%$, respectively, compared with untreated controls (Figure 1). Viability of these $\mathrm{CCl}_{4}$-exposed cells was exhibited in a dosedependent manner when pretreated with various HCIF concentrations. The percentage viability of $\mathrm{HCIF}+\mathrm{CCl}_{4}$ was less than the silymarin $+\mathrm{CCl}_{4}$, which produced $82 \%$ cell viability $(P=0.034)$ at a dose of $8 \mathrm{mM}$ compared with the $\mathrm{CCl}_{4}$-treated control group.

$\mathrm{CCl}_{4}$-induced hepatocyte cell lines expressed high levels of GOT and GPT as shown in Figure 2. However, GOT (39.8 IU/L) and GPT (44.3 IU/L) levels were reduced in the $4 \mathrm{mg} / \mathrm{mL}$ HCIF-treated HepG2 cells and significantly reduced by $60.1 \%(P=0.000)$ and $64.5 \%(P=0.000)$, respectively, compared with the control group. Likewise, HCIF effectively and significantly lowered levels of GPT (33.4 IU/L; $P=0.000)$ and GOT (34.2 IU/L; $P=0.002)$ in Chang cells. Silymarin also caused a significant reduction in GOT and GPT leakage $(P=0.000)$ at $4 \mathrm{mg} / \mathrm{mL} \mathrm{HCIF}$.

\section{Effect of $\mathrm{HCIF}$ on $\mathrm{CCl}_{4}$-induced hepatotoxicity in vivo}

$\mathrm{CCl}_{4}$ treatment caused a significant elevation of serum GOT, GPT, ALP and LDH activities (5-, 10-, 2- and 3.5fold, respectively) in rats. These elevated activities were significantly decreased by $50 \mathrm{mg} / \mathrm{kg}$ BW HCIF treatment [49.5\% $(P=0.000), 55.5 \%(P=0.000), 30.8 \%(P=0.000)$ and $45.6 \%(P=0.000)$, respectively]. Silymarin also significantly reduced the $\mathrm{CCl}_{4}$-induced elevation of serum enzymatic activities at $50 \mathrm{mg} / \mathrm{kg} \mathrm{BW}$ concentration $(P=0.000)$. In the $\mathrm{CCl}_{4}$-induced acute hepatitis model (Table 1 ), inhibitory effects of HCIF on the release of GOT and GPT into rat serum were similar to or lower than the corresponding effects mediated by silymarin $(50 \mathrm{mg} / \mathrm{kg} \mathrm{BW})$. The reduction of GOT, GPT, ALP and LDH levels after administration of HCIF could indicate the stabilization of the plasma membrane in liver and repair of hepatic tissue damage caused by $\mathrm{CCl}_{4}$.

\section{Effect of HCIF on CYP2E1 expression}

Silymarin decreased CYP2E1 protein levels in vitro and in vivo (Figures 3 and 4, lane 3). CYP2E1 expression in Chang cells was suppressed by HCIF treatment in a 


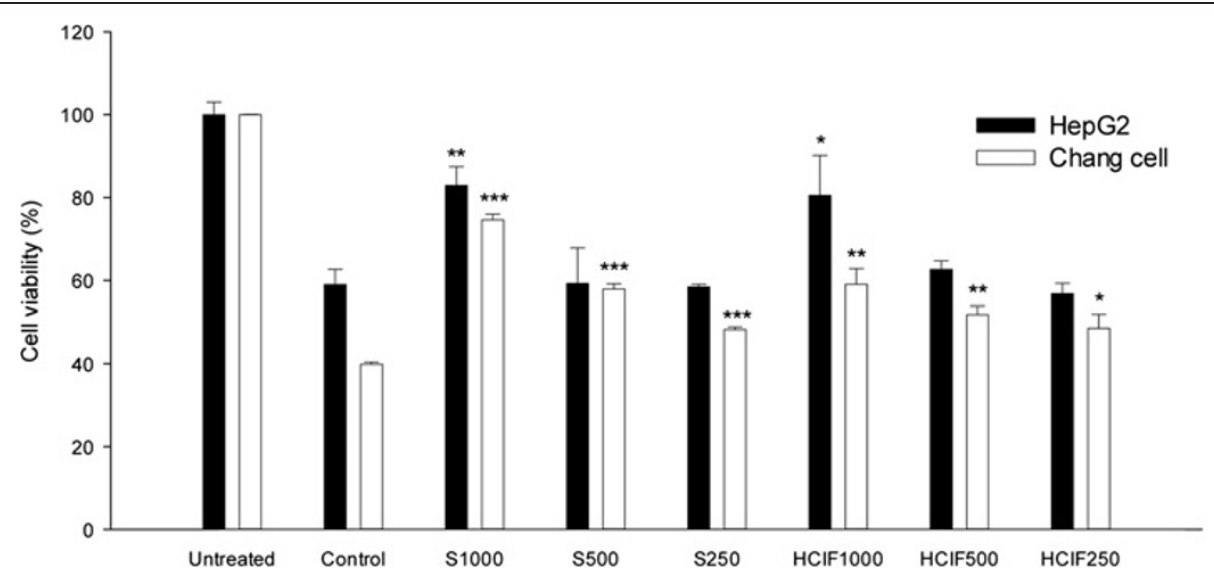

Figure 1 Protective effect of the Chrysanthemum indicum L. flower hot water extract (HCIF) against $\mathrm{CCl}_{4}$-induced cytotoxicity in a hepatocyte cell line. Untreated, cells alone; Control, cells $+\mathrm{CCl}_{4}$; , cell $+\mathrm{CCl}_{4}+$ silymarin; $\mathrm{HCIF}$, cell $+\mathrm{CCl}_{4}+\mathrm{HCIF}^{*} P<0.05$, ${ }^{* *} P<0.01$ and ${ }^{* * *} P<0.001$, significantly different from the control group.
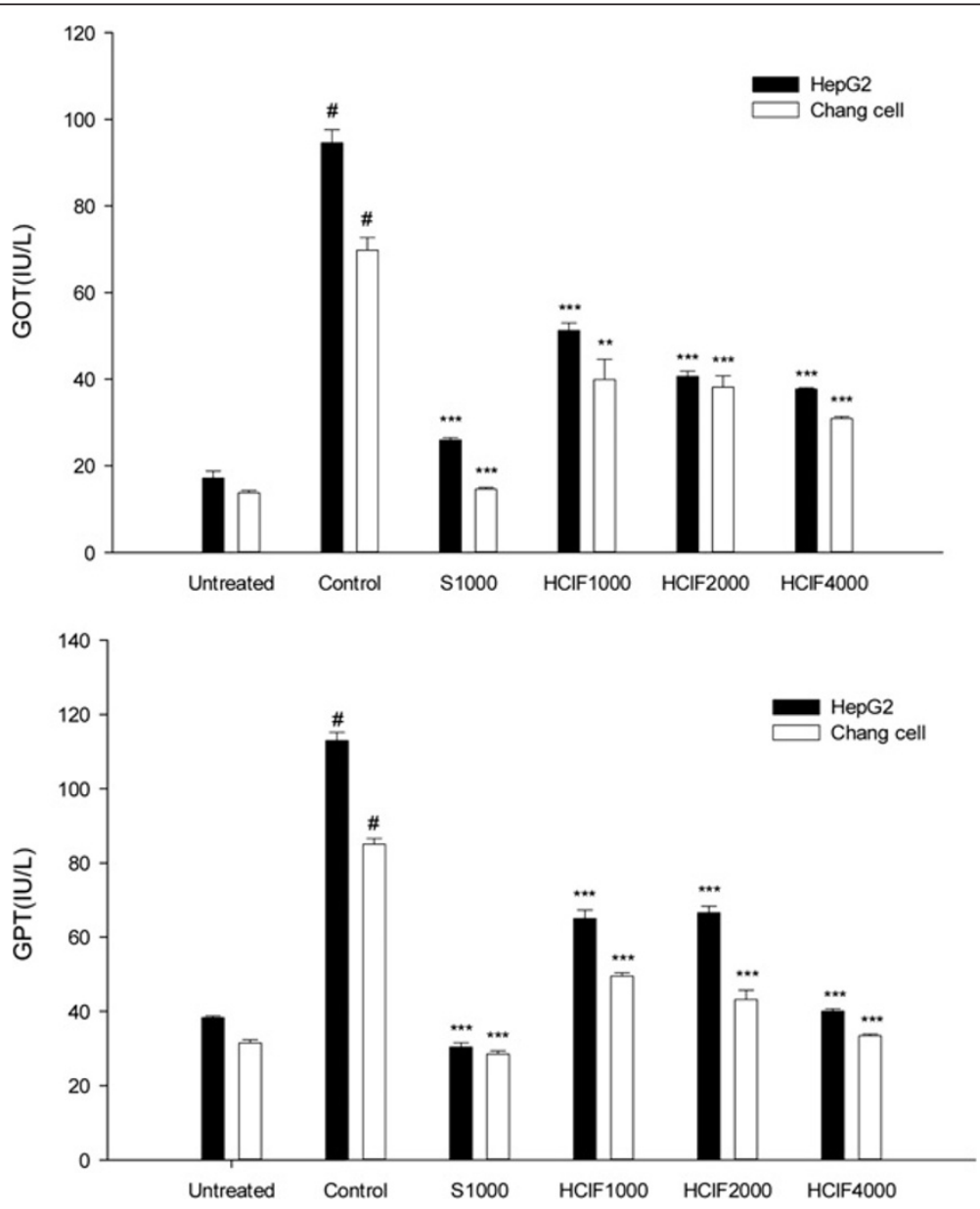

Figure 2 Effect of HCIF on GOT and GPT leakage in a hepatocyte cell line. Untreated, cells alone; Control, cells $+\mathrm{CCl}_{4} ; \mathrm{S}, \mathrm{cell}+\mathrm{CCl}_{4}+$ silymarin (1 mg/mL); HCIF, exposed to cell $+\mathrm{CCl}_{4}+\mathrm{CIF}(1,2$ and $4 \mathrm{mg} / \mathrm{mL}) .{ }^{*} P<0.05,{ }^{* *} P<0.01$ and ${ }^{* * *} P<0.001$, significantly different from the control group. ${ }^{\#} P<0.001$, significantly different from the untreated group. 
Table 1 Hepatoprotective effect of $\mathrm{HCIF}$ on $\mathrm{CCl}_{4}$-induced toxicity in rats

\begin{tabular}{ccccc}
\hline & GOT (IU/L) & GPT (IU/L) & ALP (IU/L) & LDH (IU/L) \\
\hline Untreated & $41.4 \pm 5.9$ & $14.2 \pm 0.4$ & $161.6 \pm 16.7$ & $720.4 \pm 51.1$ \\
$\mathrm{CCl}_{4}$-treated control & $197.3 \pm 10.4^{\#}$ & $148.6 \pm 9.6^{\#}$ & $330.5 \pm 36.3^{\#}$ & $2516.2 \pm 439.4^{\#}$ \\
Silymarin $+\mathrm{CCl}_{4}(50 \mathrm{mg} / \mathrm{kg})$ & $71.5 \pm 4.9^{* * *}$ & $60.5 \pm 6.8^{* * *}$ & $202.3 \pm 34.2^{* * *}$ & $1122.1 \pm 135.5^{* * *}$ \\
$\mathrm{HCIF50}+\mathrm{CCl}_{4}(50 \mathrm{mg} / \mathrm{kg})$ & $99.5 \pm 7.8^{* * *}$ & $66.1 \pm 14.0^{* * *}$ & $228.7 \pm 26.3^{* * *}$ & $1368.6 \pm 144.3^{* * *}$ \\
\hline
\end{tabular}

Serum GOT, GPT, ALP and LDH levels were determined by commercial kits. Each value is the mean $\pm S D ; n=9$ rats. ${ }^{*} P<0.001$, significantly different from the untreated group. ${ }^{* * *} P<0.01$, significantly different from the $\mathrm{CCl}_{4}$-treated control group.

dose-dependent manner (Figure 3, lanes 4-6). CYP2E1 levels were also reduced to $43.1 \%(P=0.018)$ in vivo at a dose of $50 \mathrm{mg} / \mathrm{kg} \mathrm{BW}$ (Figure 4, lane 4).

\section{Histopathological examination}

We examined whether HCIF could affect anatomical changes in injured liver tissue. Photomicrographs of hematoxylin and eosin-stained liver tissue are shown in Figure 5. Histopathological changes were prominent compared with those in rats in the untreated (group I) and control (group II) groups. No histological abnormalities were observed of group I (Figure 5A). However, hepatocytes around the central vein revealed complete necrosis (arrow b) and loss of the cellular boundary (Figure 5B) in group II. Additionally, hepatic cells were found to have fatty degeneration (arrow c) and cytoplasmic vacuolization (arrow a). Numerous diffuse ballooning degeneration of different sizes and larger magnitude

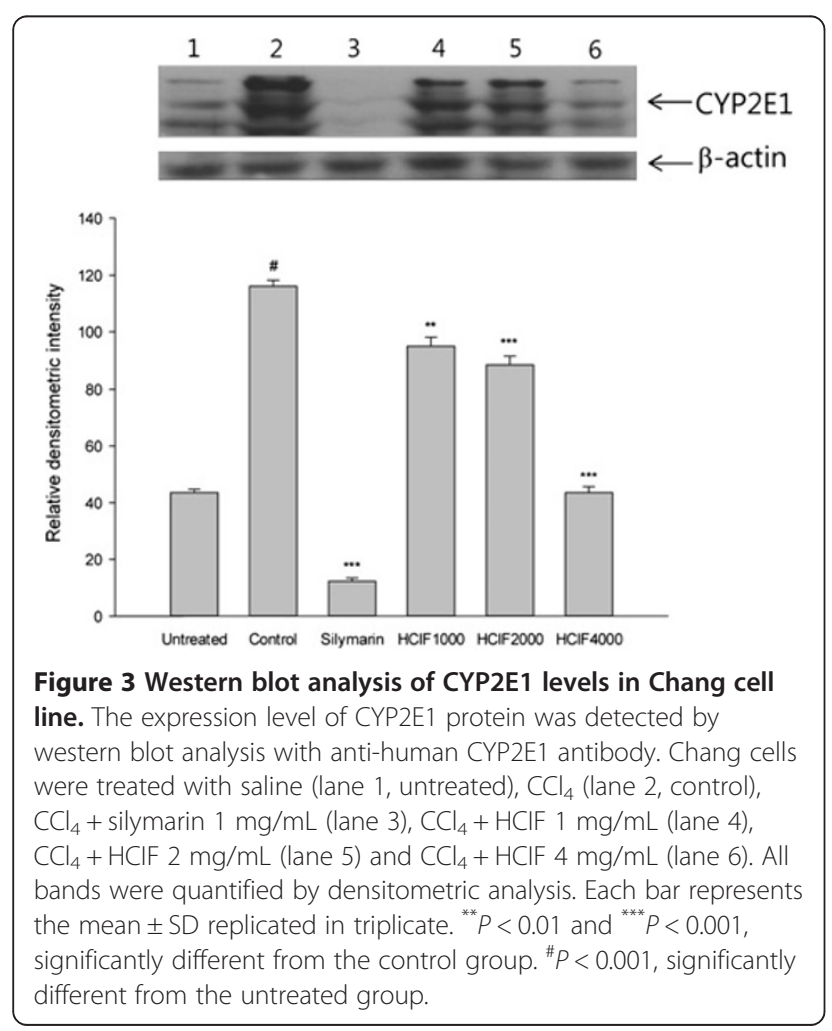

compared with group I was observed. Pretreatment of HCIF (Figure 5D and E) resulted in less severe histopathological alterations compared with group II. Furthermore, remarkable changes, such as less ballooning degeneration, cytoplasmic vacuolization and fatty degeneration, were observed in the $\mathrm{CCl}_{4}+\mathrm{HCIF}$-treated rat livers compared with that of group II. The numbers of $\mathrm{CCl}_{4}$-induced histopathological alterations were dramatically decreased in the HCIF-treated (group IV and V) and $50 \mathrm{mg} / \mathrm{kg}$ silymarin treatment (group III) groups.

\section{Discussion}

Water extracts derived from many natural products possess hepatoprotective effects $[28,29]$. The hepatoprotective effects of HCIF were investigated in this study. $\mathrm{CCl}_{4}$-induced toxicity is commonly used to study the hepatoprotective effects of drugs or medicinal plant extracts using in vivo and in vitro techniques $[14,30]$. Usually, the extent of hepatic damage is assessed by histopathological examination and measurement of GOT, GPT and ALP levels released into

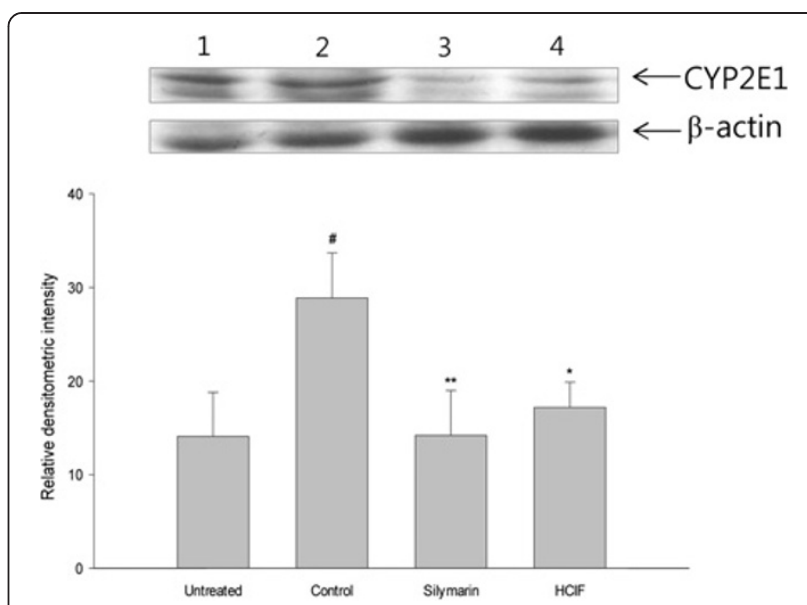

Figure 4 Western blot analysis of CYP2E1 levels in rat liver. The expression level of CYP2E1 was detected by western blot analysis of protein samples from rat liver. Rats were treated with olive oil (lane 1, untreated), $\mathrm{CCl}_{4}+$ saline (lane 2, control), $\mathrm{CCl}_{4}+$ silymarin $50 \mathrm{mg} / \mathrm{kg} \mathrm{BW}$ (lane 3, silymarin) and $\mathrm{CCl}_{4}+\mathrm{CIF} 50 \mathrm{mg} / \mathrm{kg}$ BW (lane 4, HCIF) for 7 days. All hepatotoxicity was induced in rats with $1 \mathrm{mg} / \mathrm{kg}$ body weight of $\mathrm{CCl}_{4}$. All bands were quantified by densitometric analysis. ${ }^{*} P<0.05$ and ${ }^{* * *} P<0.01$, significantly different from the control group. ${ }^{\#} P<0.01$, significantly different from the untreated group. 

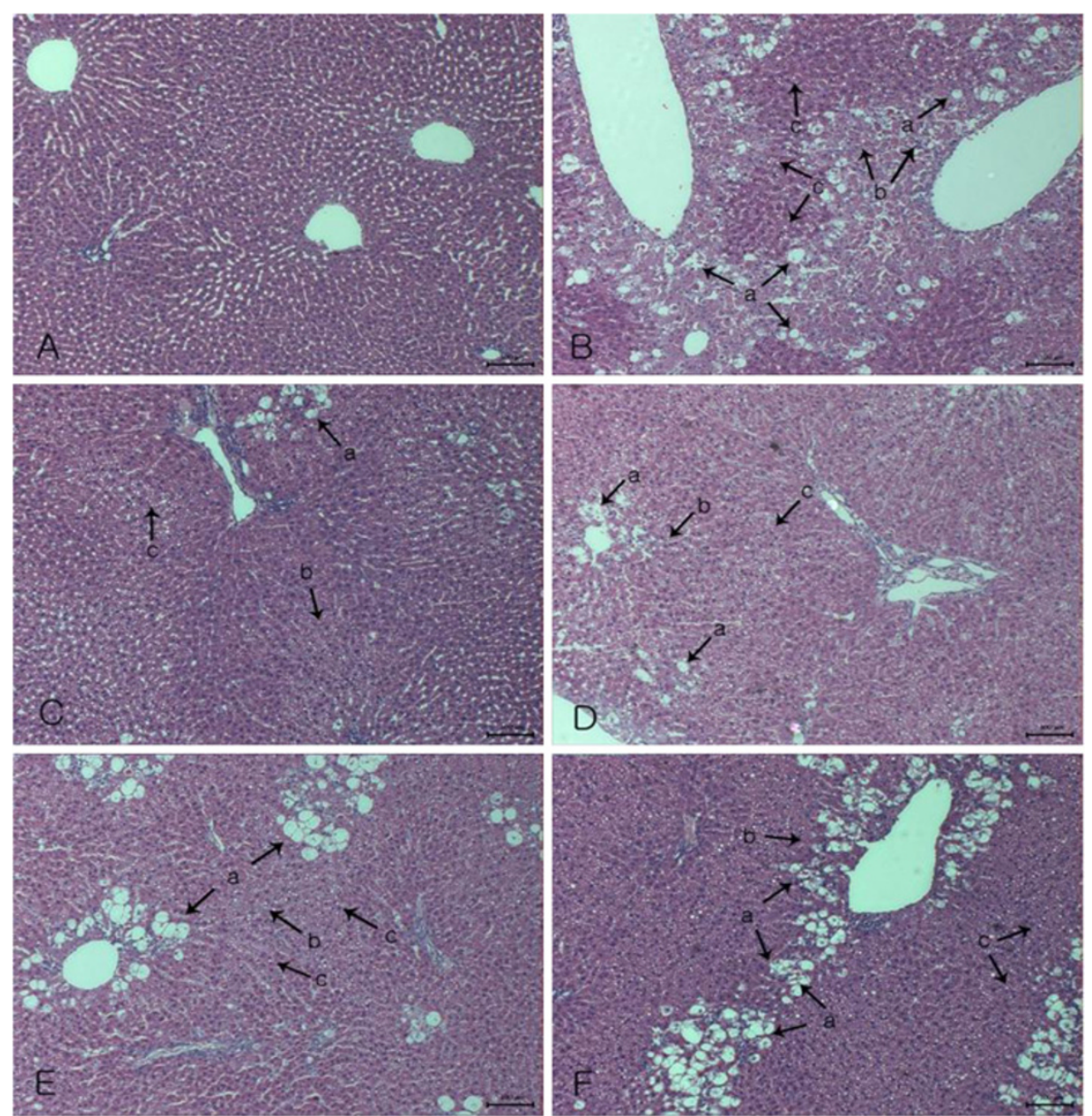

Figure 5 Photomicrographs of paraffin-embedded rat liver. Each sample was pretreated for 7 days and then treated with a single dose of $\mathrm{CCl}_{4}$. (A) untreated group (group I); (B) $\mathrm{CCl}_{4}$ alone (group II); (C) silymarin (50 mg/kg BW, group III); (D) HCIF (50 mg/kg BW, group IV); (E) HCIF (100 mg/kg BW, group V); (F) tea seed oil (200 mg/kg BW, group VI). All hepatotoxicity was induced in rats with $1 \mathrm{mg} / \mathrm{kg}$ body weight of CCl and analyzed $24 \mathrm{~h}$ later. Each of the arrows indicated vacuole formation (a), necrosis (b) and fatty degeneration (c).

serum [31,32]. This work demonstrated that HCIF significantly affected $\mathrm{CCl}_{4}$-induced hepatotoxicity in hepatocyte cell lines and rats. Recovery of normal serum levels of transaminases indicated healing of hepatic parenchyma and regeneration of hepatocytes [33]. In this study, enzyme levels significantly decreased to $49.5 \%$ and $55.5 \%$ at $50 \mathrm{mg} /$ $\mathrm{kg}$ BW dose of HCIF, suggesting that HCIF has a potent hepatoprotective effect on $\mathrm{CCl}_{4}$-treated rats. GOT and GPT levels in hepatocytes in this cell culture study were comparable to in vivo results.

The hepatocellular carcinoma cell line HepG2 is a reliable model that is easy to culture, well characterized and widely used for biochemical and drug toxicity studies. HepG2 cells possess many morphological and biochemical features of normal hepatocytes, and many hepatoprotective compounds have been studied using HepG2 cells [34-38]. Silymarin or its main ingredient silibinin can inhibit cancer cells [39]. In this study, silymarin increased cell viability resulting from $\mathrm{CCl}_{4}$-induced hepatotoxicity. The mechanism of $\mathrm{CCl}_{4}$-induced damage involves the biotransformation of $\mathrm{CCl}_{4}$ into a highly reactive trichloromethyl free radical $\left(\mathrm{CCl}_{3}{ }^{\circ}\right)$. Silymarin is a new hepatoprotective agent [40], which scavenges radicals, prevents glutathione (GSH) oxidation and depletion and stabilizes membranes [41-43]. Many previous reports have confirmed that many antioxidants decrease toxicity and lipid peroxidation induced by $\mathrm{CCl}_{4}[44,45]$. Shear et al. [42] studied HepG2 cell viability with silymarin, which increased HepG2 cell viability against the oxidative metabolite of acetaminophen. In the present study, we did not investigate whether HCIF has anticancer effects.

Western blotting was performed on total protein samples isolated from rat liver homogenates and Chang cells to assess CYP2E1 protein expression. CYP2E1 has been demonstrated to be largely responsible for the activation 
of $\mathrm{CCl}_{4}$ to its toxic metabolites [46], and pretreatment of rats with CYP2E1 inhibitors can protect against $\mathrm{CCl}_{4}$-induced hepatotoxicity [47]. We found decreased expression of CYP2E1 protein in HCIF-treated Chang cells (Figure 3) and hepatic microsomes in HCIF-treated rats (Figure 4). The phytochemical profile of HCIF contains large amounts of caffeic acid, luteolin, kaempferol, flavonoids, terpenoids and phenolic compounds [13,48]. Polyphenols, which are strong antioxidants, prevent ethanol-induced CYP2E1 expression in HepG2 cells [49]. The downregulation of CYP2E1 expression decreases the formation of $\mathrm{CCl}_{3}^{*}$ and reduces hepatocyte necrosis and hepatocellular injury [47]. Several previous studies have demonstrated that $\mathrm{CCl}_{4}$-induced hepatotoxicity could be modulated by substances that influence CYP2E1 activity [50,51]. In particular, compounds or drugs that induce CYP2E1 could potentiate the hepatic toxicity of $\mathrm{CCl}_{4}[52,53]$. Compounds that inhibit CYP2E1 could protect cells against $\mathrm{CCl}_{4}$-induced toxicity $[22,46]$. The induction or inhibition of $\mathrm{CCl}_{4}$ biotransformation may subsequently influence metabolic activation or detoxification of $\mathrm{CCl}_{4}$. Generally, CYP2E1 participates in the metabolism of small organic molecules, such as carbon tetrachloride, acetaminophen and nitrosamines [15,17,54]. Thus, CYP2E1 inhibition by HCIF not only protects cells against $\mathrm{CCl}_{4}$-induced hepatotoxicity, but also reduces xenobiotic toxicity.

$\mathrm{CCl}_{4}$ causes increased formation of pro-oxidants (trichloromethyl radical) and a concomitant decrease in the antioxidant status of the cell [55]. Overproduction of oxygen radicals causes an imbalance in oxidantantioxidant capacity and increased attacks on unsaturated fatty acid of lipid structures leading to lipid peroxidation and damaging effects on proteins [56]. These pro-oxidant molecules attack microsomal lipids and form peroxidation products $[57,58]$. Changes in biochemical indices and histopathological appearance in $\mathrm{CCl}_{4}$-treated rats were significant when compared with the untreated group (group I). HCIF-pretreated rats showed a significant hepatoprotective effect of $\mathrm{HCIF}$ against $\mathrm{CCl}_{4}$-induced liver injury in rats. The histopathological appearance and biochemical indices of $50 \mathrm{mg} / \mathrm{kg}$ BW HCIF-pretreated rats were similar to that of the untreated group (group I). $\mathrm{CCl}_{4}$ treatment of rats markedly increased serum ALP and LDH levels, which reflect the severity of liver injury [59]. Large quantities of ALT and LDH secreted into serum may be associated with severe liver injury. As previously reported, CIF has a large amount of phenolic compounds, and the water extract of CIF exhibited high antioxidant activity [60]. Lipid peroxidation, the principal cause of $\mathrm{CCl}_{4}$-induced liver injury, is associated with the freeradical metabolite of $\mathrm{CCl}_{4}$. One of the hepatoprotective activities of HCIF may also result from its antioxidative properties.

\section{Conclusions}

$\mathrm{HCIF}$ inhibited bioactivation of $\mathrm{CCl}_{4}$-induced hepatotoxicity and downregulated CYP2E1 expression in vitro and in vivo.

\section{Abbreviations}

ALP: Alkaline phosphatase; BSA: Bovine serum albumin; BW: Body weight; $\mathrm{CCl}_{4}$ : Carbon tetrachloride; CIF: Chrysanthemum indicum L. flower; CYP2E1: Cytochrome P450 2E1 protein; DMEM: Dulbecco's modified Eagle's medium; DMSO: Dimethyl sulfoxide; EDTA: Ethylenediaminetetraacetic acid; FBS: Fetal bovine serum; GOT: Glutamic oxaloacetic transaminase; GPT: Glutamic pyruvic transaminase; HCIF: Hot water extract of CIF; HepG2: Hepatocellular carcinoma cell line; LDH: Lactate dehydrogenase; MTT: 3-(4,5-dimethylthiazol-2-yl)-2,5-diphenyltetrazolium bromide; NO: Nitric oxide.

\section{Competing interests}

The authors declare that they have no competing interests.

\section{Author's contributions}

CHS, SCJ and SMK designed the study and wrote the manuscript. SCJ, SMK and YTJ performed the experiments. SCJ, SMK, CHS and YTJ analyzed the data. All authors read and approved the final manuscript.

\section{Acknowledgements}

This work was supported by a 2009 Daegu University research grant.

Received: 24 October 2012 Accepted: 1 April 2013

Published: 4 April 2013

\section{References}

1. Brattin WJ, Glende EA, Recknagel RO: Pathological mechanisms in carbon tetrachloride hepatotoxicity. Free Radic Biol Med 1985, 1:27-38.

2. Recknagel RO, Glende EA, Dolak JA, Waller RL: Mechanisms of carbon tetrachloride toxicity. Pharmacol Ther 1989, 43:139-54.

3. Recknagel RO, Glende EA, Britton RS: Free radical damage and lipid peroxidation. In Hepatotoxicology. Edited by Meeks RG. Boca Raton: CRC Press, Inc; 1991:401-36.

4. Jiangsu new medical college: Dictionary of Chinese material medical science and technology. Shanghai: Press of Shanghai; 1993.

5. Matsuda H, Morikawa T, Toguchida I, Harima S, Yoshikawa M: Medicinal flowers VI. Absolute stereostructures of two new flavanone glycosides and phenylbutanoid glycoside from the flowers of Chrysanthemum indicum L., there inhibitory activities for rat lens aldose reductase. Chem Pharm Bull 2002, 50:972-5.

6. Kato T, Noguchi K, Miyamoto Y, Suekawa M, Aburada M, Hosoya E, Sakanashi M: Effects of Chrysanthemum indicum Linn. on coronary, vertebral, renal and aortic blood flows of the anesthetized dog. Arch Int Pharmacodyn Ther 1987, 285:288-300.

7. Yu DQ, Xie FZ, He WY, Liang XT: Application of 2D NMR techniques in the structure determination of chrysanthetriol. Yao Xue Xue Bao 1992, 27:191-6.

8. Cheng W, Li J, You T, Hu C: Anti-inflammatory and immunomodulatory activities of the extracts from the inflorescence of Chrysanthemum indicum Linne. J Ethnopharmacol 2005, 101:334-7.

9. Shunying Z, Yang Y, Huaidong Y, Yue Y, Guolin Z: Chemical composition and antimicrobial activity of the essential oils of Chrysanthemum indicum. J Ethnopharmacol 2005, 96:151-8.

10. Yan YC, Lou XE, Jiang HD: Experimental studies on the anti-oxidation effects of water extract from Chrysanthemum indicum. Zhong Guo Xian Dai Ying Yong Yao Xue Za Zhi 1999, 16:16-8.

11. Liu YG: Pharmacological study and clinical apply of Chrysanthemum indicum. Shi Zhen Guo Yao 1991, 2:103.

12. Kong LD, Cai Y, Huang WW, Cheng CHK, Tan RX: Inhibition of xanthine oxidase by some Chinese medicinal plants used to treat gout. J Ethnopharmacol 2000, 73:199-207.

13. Yoshikawa M, Morikawa T, Toguchida I, Harima S, Matsuda H: Medicinal flowers II, Inhibitors of nitric oxide production and absolute stereostructures of five new germacrane-type sesquiterpenes, kikkanols 
$D, D$ monoacetate, $E, F$, and $F$ monoacetate from the flowers of Chrysanthemum indicum L. Chem Pharm Bull 2000, 48:651-6.

14. Kiso Y, Tohkin M, Hikino H: Mechanism of antihepatotoxic activity of glycyrrhizin I, Effect on free radical generation and lipid peroxidation. Planta Med 1984, 50:298-302.

15. Koop DR: Oxidative and reductive metabolism by cytochrome P450 2E1. FASEB J 1992, 6:724-30.

16. Raucy JL, Kraner JC, Lasker JM: Bioactivation of halogenated hydrocarbons by cytochrome P4502E1. Crit Rev Toxicol 1993, 23:1-20.

17. Zangar RC, Benson JM, Burnett VL, Springer DL: Cytochrome P450 2E1 is the primary enzyme responsible for low-dose carbon tetrachloride metabolism in human liver microsomes. Chem Biol Interact 2000, 125:233-43.

18. Jeong HG: Inhibition of cytochrome P450 2E1 expression by oleanolic acid, hepatoprotective effects against carbon tetrachloride-induced hepatic injury. Toxicol Lett 1999, 105:215-22.

19. Kim ND, Kwak MK, Kim SG: Inhibition of cytochrome P450 2E1 expression by 2-(allylthio) pyrazine, a potential chemoprotective agent, hepatoprotective effects. Biochem Pharmacol 1997, 53:261-9.

20. Nebert DW, Nelson DR, Coon MJ, Estabrook RW, Feyereisen R, Fujii-Kuriyama , Gonzalez FJ, Peter Guengerich F, Gunsalus IC, Johnson EF, Loper JC, Sato R, Waterman MR, Waxman DJ: The P450 superfamily, Update on new sequences, gene mapping and recommended nomenclature. DNA Cell Biol 1991, 10:1-14.

21. Chrungoo VJ, Singh K, Singh J: Silymarin mediated differential modulation of toxicity induced by carbon tetrachloride, paracetamol and -galactosamine in freshly isolated rat hepatocytes. Indian J Exp Biol 1997, 35:611-7.

22. Hinkino H, Kiso $\mathrm{Y}$, Wagner $\mathrm{H}$ : Anti-hepatotoxic actions of flavonolignans from Silibum marianum fruits. Planta Med 1984, 50:248-50.

23. Miyazawa T, Suzuki T, Fujimoto K, Kaneda T: Phospholipid hydroperoxide accumulation in liver of rats intoxicated with carbon tetrachloride and its inhibition by dietary alpha-tocopherol. J Biochem 1990, 107:689-93.

24. Shibayama Y: Endotoxaemia and hepatic injury in obstructive jaundice. J Pathol 1989, 159:335-9.

25. Yoshitake I, Ohishi E, Sano J, Mori T, Kubo K: Effects of KF-14363 on liver fibrosis in rats with chronic liver injury induced by carbon tetrachloride. J Pharm Dyn 1991, 14:679-85.

26. Reitman S, Frankel S: A colorimetric method for the determination of serum glutamate oxaloacetate transaminases. Am J Clin Pathol 1957, 28:56-63.

27. Kind PRN, Kings EJ: Determination of serum bilirubin. J Clin Pathol 1976, 7:322-30.

28. Chen J, Mao D, Yong Y, Li J, Wei H, Lu L: Hepatoprotective and hypolipidemic effects of water-soluble polysaccharidic extract of Pleurotus eryngii. Food Chem 2012, 130:687-94.

29. You YH, Yoo SN, Yoon HG, Park JJ, Lee YH, Kim SO, Oh KT, Lee JG, Cho HY, Jun WJ: In vitro and in vivo hepatoprotective effects of the aqueous extract from Taraxacum officinale (dandelion) root against alcoholinduced oxidative stress. Food Chem Toxicol 2010, 48:1632-7.

30. Allis JW, Ward TR, Seely JC, Simmons JE: Toxic effects of carbon tetrachloride on rats. Fundam Appl Toxicol 1990, 15:558-70.

31. Plaa G, Charbonneau M: Detection and evaluation of chemically induced liver injury. In Principles and Methods of Toxicology. Edited by Hayes AW. New York: Raven Press; 1994:841-6.

32. Drotman RB, Lawhorn GT: Serum enzymes as indicators of chemically induced liver damage. Drug Chem Toxicol 1978, 1:163-71.

33. Thabrew MI, Joice PD, Rajatissa W: A comparative study of the efficacy of Pavetta indica and Osbeckia octandra in the treatment of liver dysfunction. Planta Med 1987, 53:239-41.

34. Alía M, Ramos S, Mateos R, Bravo L, Goya L: Response of the antioxidant defense system to t-Butyl hydroperoxide and hydrogen peroxide in a human hepatoma cell line (HepG2). J Biochem Mol Toxicol 2005, 19:1 19-128.

35. Sassa S, Sugita O, Galbraith RA, Kappas A: Drug metabolism by the human hepatoma cell, HepG2 27. Biochem Biophys Res Commun 1987, 143:52-57.

36. Bouma ME, Rogier E, Verthier N, Labarre C, Feldmann G: Further cellular investigation of the human hepatoblastoma-derived cell line HepG2, morphology and immunocytochemical studies of hepatic-secreted proteins. In Vitro Cell Dev Biol 1989, 25:267-275.

37. Senthil Kumar KJ, Liao JW, Xiao JH, Gokila Vani M, Wang SY: Hepatoprotective effect of lucidone against alcohol-induced oxidative stress in human hepatic HepG2 cells through the up-regulation of HO-1/Nrf-2 antioxidant genes. Toxicol In Vitro 2012, 26:700-708.
38. Krithika R, Mohankumar R, Verma RJ, Shrivastavc PS, Mohamad IL, Gunasekarand P, Narasimhan S: Isolation, characterization and antioxidative effect of phyllanthin against $\mathrm{CCl}_{4}$-induced toxicity in HepG2 cell line. Chem Biol Interact 2009, 181:351-358.

39. Chen $\mathrm{CH}$, Huang TS, Wong CH, Hong CL, Tsai YH, Liang CC, Lu FJ, Chang WH: Synergistic anti-cancer effect of baicalein and silymarin on human hepatoma HepG2 Cells. Food Chem Toxicol 2009, 47:638-644.

40. Crocenzi FA, Roma MG: Silymarin as a new hepatoprotective agent in experimental cholestasis, new possibilities for an ancient medication. Curr Med Chem 2006, 13:1055-1074.

41. Leng-Peschlow E, Strenge-Hesse A: Die Mariendistel (Silybum marianum) und Silymarin als Lebertherapeutikum. Z Phytother 1991, 12:162-174.

42. Shear NH, Malkiewicz IM, Klein D, Koren G, Randor S, Neuman MG: Acetaminophen-induced toxicity to human epidermoid cell line A431 and hepatoblastoma cell line HepG2, in vitro, is diminished by silymarin. Skin Pharmacol 1995, 8:279-91.

43. Dehmlow C, Murawski N, de Groot H: Scavenging of reactive oxygen species and inhibition of arachidonic acid metabolism by silibinin in human cells. Life Sci 1996, 58:1591-600.

44. Dehmlow C, Erhard J, de Groot H: Inhibition of kupffer cell functions as an explanation for the hepatoprotective properties of silibinin. Hepatology 1996, 23:749-754

45. Olnes MI, Kurl RN: Isolation of nuclear extracts from fragile cells, A simplified procedure applied to thymocytes. Biotechniques 1994, 17:828-829.

46. Johansson I, Ingelman-Sundberg M: Carbon tetrachloride-induced lipid peroxidation dependent on an ethanol-inducible form of rabbit liver microsomal cytochrome P450. FEBS Lett 1985, 183:265-9.

47. Brady JF, Xiao F, Wang M, Li Y, Ning SM, Gapac JM, Yang CS: Effects of disulfiram on hepatic P450lIE1, other microsomal enzymes, and hepatotoxicity in rats. Toxicol Appl Pharmacol 1991, 108:366-73.

48. Kentaro TN, Hiroshi S, Miyuki H: Inhibitory effects of Chrysanthemum species extracts on formation of advanced glycation end products. Food Chem 2009, 116:854-859.

49. Oliva J, Bardag-Gorce F, Tillman B, French SW: Protective effect of quercetin, EGCG, catechin and betaine against oxidative stress induced by ethanol in vitro. Exp Mol Pathol 2011, 90:295-299.

50. Lee KJ, Choi JH, Jeong HG: Hepatoprotective and antioxidant effects of the coffee diterpenes kahweol and cafestol on carbon tetrachlorideinduced liver damage in mice. Food Chem Toxicol 2007, 11:2118-25.

51. Hwang YP, Choi CY, Chung YC, Jeon SS, Jeong HG: Protective effects of puerarin on carbon tetrachloride-induced hepatotoxicity. Arch Pharm Res 2007, 30:1309-17.

52. Allis JW, Brown BL, Simmons JE, Hatch GE, McDonald A, House DE: Methanol potentiation of carbon tetrachloride hepatotoxicity, the central role of cytochrome P450. Toxicology 1996, 112:131-40.

53. Day BJ, Carlson GP, DeNicola DB: Potentiation of carbon tetrachlorideinduced hepatotoxicity and pneumotoxicity by pyridine. J Biochem Toxicol 1993, 8:11-8.

54. Guengerich FP, Kim DH, Iwasaki M: Role of human cytochrome P-450 IIE1 in the oxidation of many low molecular weight cancer suspects. Chem Res Toxicol 1991, 4:168-79.

55. Anon MT, Ubeda A, Alcaraz MJ: Protective effects of phenolic compounds on $\mathrm{CCl}_{4}$-induced toxicity in isolated rat hepatocytes. Z Naturforsch C 1992, 47:275-9.

56. Brigitte MWR: Oxygen free radicals and antioxidants in cystic fibrosis, the concept of an oxidant-antioxidant imbalance. Acta Paediatr 1994, 83:49-57.

57. Comporti M: Biology of diseases, lipid peroxidation and cellular damage in toxic liver injury. Lab Inves 1985, 53:599-623.

58. Rana SV, Singh SR, Verma S: Mercury induced lipid peroxidation in liver, kidney, brain and gills of a fresh water fish Channa punctatus. Gyoruigaku Zasshi 1995, 42:255-9.

59. Lin SC, Yao CJ, Lin CC, Lin YH: Hepatoprotective activity of Taiwan folk medicine, Eclipta prostrate Linn. against various hapatotoxins induced acute hapatotoxicity. Phytother Res 1996, 10:483-90.

60. Kalyarat K, Kaew K: Antioxidant activity, phenolic content and antimutagenic activity of some water extract of herbs. Thai J Pharm Sci 2006, 30:28-35.

doi:10.1186/1749-8546-8-7

Cite this article as: Jeong et al:: Hepatoprotective effect of water extract from Chrysanthemum indicum L. flower. Chinese Medicine 2013 8:7. 